\title{
Self-assembled multivalent (SAMul) ligand systems with enhanced stability in the presence of human serum
}

Marta Tena-Solsona, a Domenico Marson, ${ }^{\mathrm{b}}$ Ana C. Rodrigo, ${ }^{\mathrm{a}}$ Stephen M. Bromfield, ${ }^{a}$ Beatriu Escuder, ${ }^{b}$ Juan F. Miravet, ${ }^{b}$ Nadezda Apostolova, ${ }^{c}$ Erik Laurini, ${ }^{d}$ Sabrina Pricl, ${ }^{* d}$ and David K. Smith*a

a: Department of Chemistry, University of York, Heslington, York, YO10 5DD, UK Email: david.smith@york.ac.uk

b: Departament de Química Inorgànica i Orgànica, Universitat Jaume I, Av. Sos Baynat, s/n, 12071 Castelló, Spain

c: Department of Pharmacology, University of Valencia, Avda. Blasco Ibañez n. 15-17, Valencia 46010, Spain

d: Molecular Biology and Nanotechnology Laboratory (MolBNL@UniTS), DEA, University of Trieste, Trieste, 34127, Italy

\section{SUPPORTING INFORMATION}

1 Materials and Methods

2 Synthesis and Characterisation Data

3 Nile Red Assay

4 Transmission Electron Microscopy

5 Mallard Blue Assay

6 Isothermal Calorimetry

7 Degradation Assay

8 Computational Simulation of Micelle Stabilty

9 Cell Viability Assay

10 NMR Spectra

11 References 


\section{Materials and Methods}

All reagents were obtained from commercial sources and were used without further purification. Sodium salt heparin from porcine intestinal mucosa with a molecular weight between 15,000 \pm 2,000 Da (192 IU mg $\mathrm{m}^{-1}$ ) was obtained from Calbiochem. Trizma hydrochloride (Tris $\mathrm{HCl}$ ) and Human Serum were obtained from Sigma Aldrich. Mallard Blue (MalB) was prepared as previously described ${ }^{23}$ and stored in the dark. Column chromatography was performed on silica gel $60(35-70 \mu \mathrm{m})$ supplied by Fluka Ltd. Preparative gel permeation chromatography (GPC) was performed on Biobeads SX-1 supplied by Bio-Rad. Thin layer chromatography was performed on Merck aluminium-backed plates, coated with $0.25 \mathrm{~nm}$ silica gel $60 .{ }^{1} \mathrm{H},{ }^{13} \mathrm{C},{ }^{1} \mathrm{H}-{ }^{1} \mathrm{H}$ COSY and ${ }^{1} \mathrm{H}_{-}{ }^{13} \mathrm{C}$ HSQC NMR were recorded on JEOL ECX400 spectrometer. ESI and HR-ESI mass spectra were recorded on a Bruker Daltonics Micro-TOF mass spectrometer. Absorbance was measured on a Shimadzu UV-2401PC spectrophotometer and fluorescence on a Hitachi F-4500. All experiments were performed in triplicate. For the purpose of calculations, the molecular weight of heparin is assumed as that of the sodiated analogue of a standard heparin repeat unit: namely $665.40 \mathrm{~g} \mathrm{~mol}^{-1}$, and four anionic charges are assumed per repeat unit. It should be noted that as supplied, heparin only contains ca. $30-40 \%$ of material with the active sequence of repeat units. However, all the sample contains anionic saccharide units which can bind to cationic species, even if they are in the wrong sequence. Hence to best evaluate binding concentrations and charge efficiencies, we report the total concentration of the anionic disaccharide (irrespective of whether it is present in the active form of heparin or not). However, all presented data which refers to the dose of binders (in $\mathrm{mg} /$ units) refers to their ability to bind only the specific clinically active heparin.

\section{Synthesis and Characterisation Data}

Compounds $\mathbf{1 - 2},{ }^{181} \mathbf{3}-\mathbf{4}^{312} \mathbf{5}, \mathbf{7},{ }^{17 a 3} \mathbf{6}^{32{ }^{4}} \mathbf{8}^{205} \mathbf{9}^{216} \mathbf{1 1 - 1 4 ^ { 1 1 } 7}$ were synthesised using established methodologies and characterisation data were in agreement with those previously published. 


\section{Synthetic Schemes}
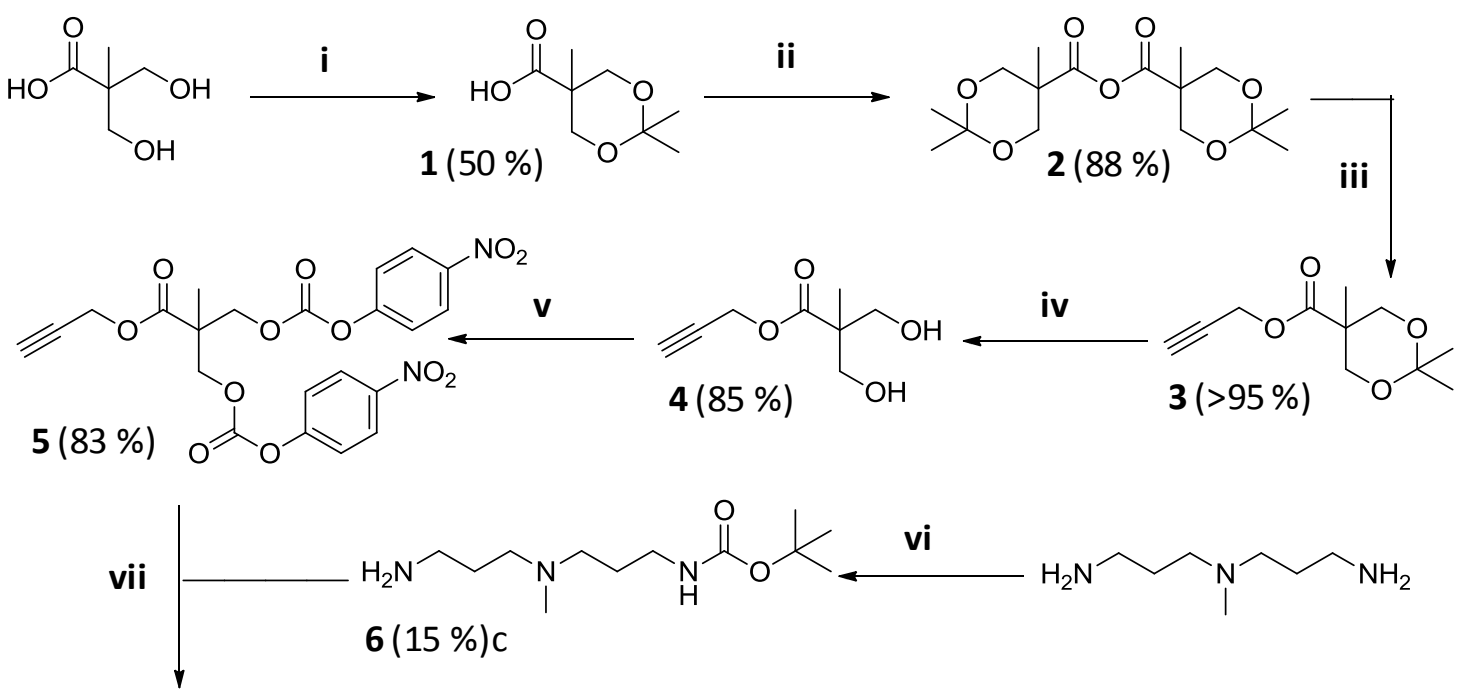<smiles>C#CCOC(=O)C(C)(CO)COC(=O)NCCCN(C)CCCNC(=O)OC(C)(C)C</smiles>

$7(>95 \%)$<smiles>CN(CCCNC(=O)OC(C)(C)C)CCCNC(=O)OC(C)(C)C</smiles>

Scheme S1. Synthesis of alkyne-modified dendron $7 .^{1-4}$

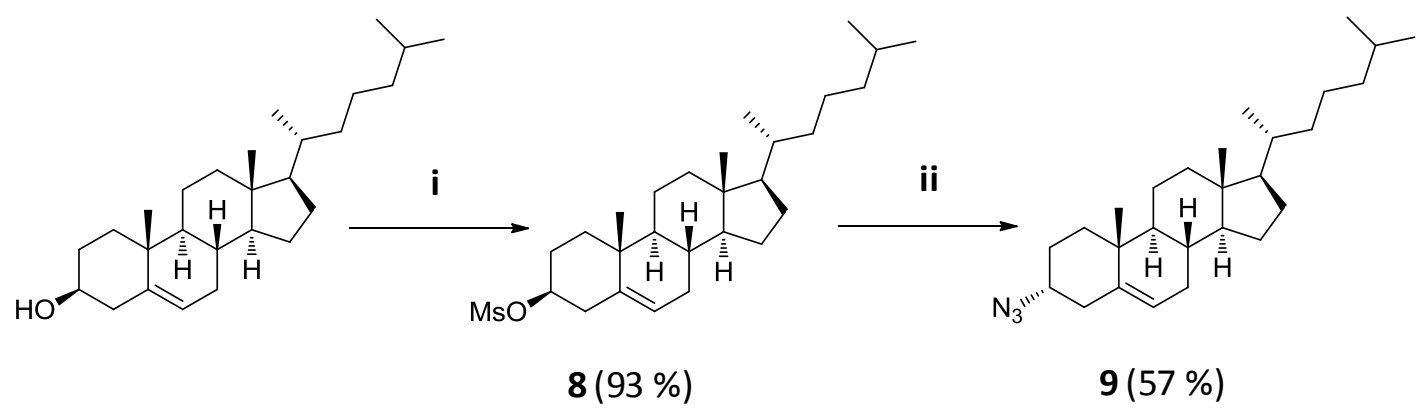

Scheme S2. Synthesis of azide-modified cholesterol 9.,6 


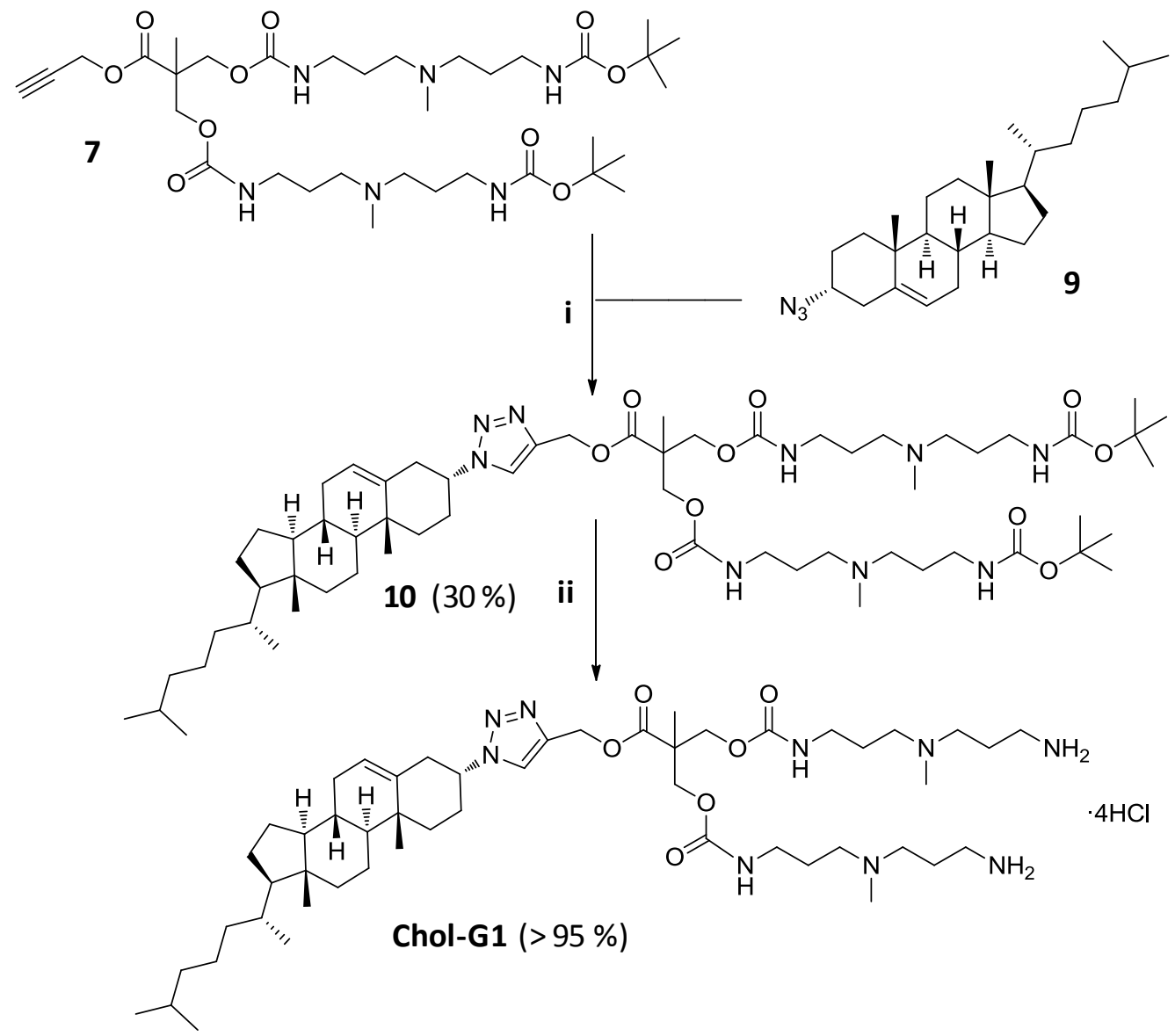

Scheme S3. Synthesis of Chol-G1.
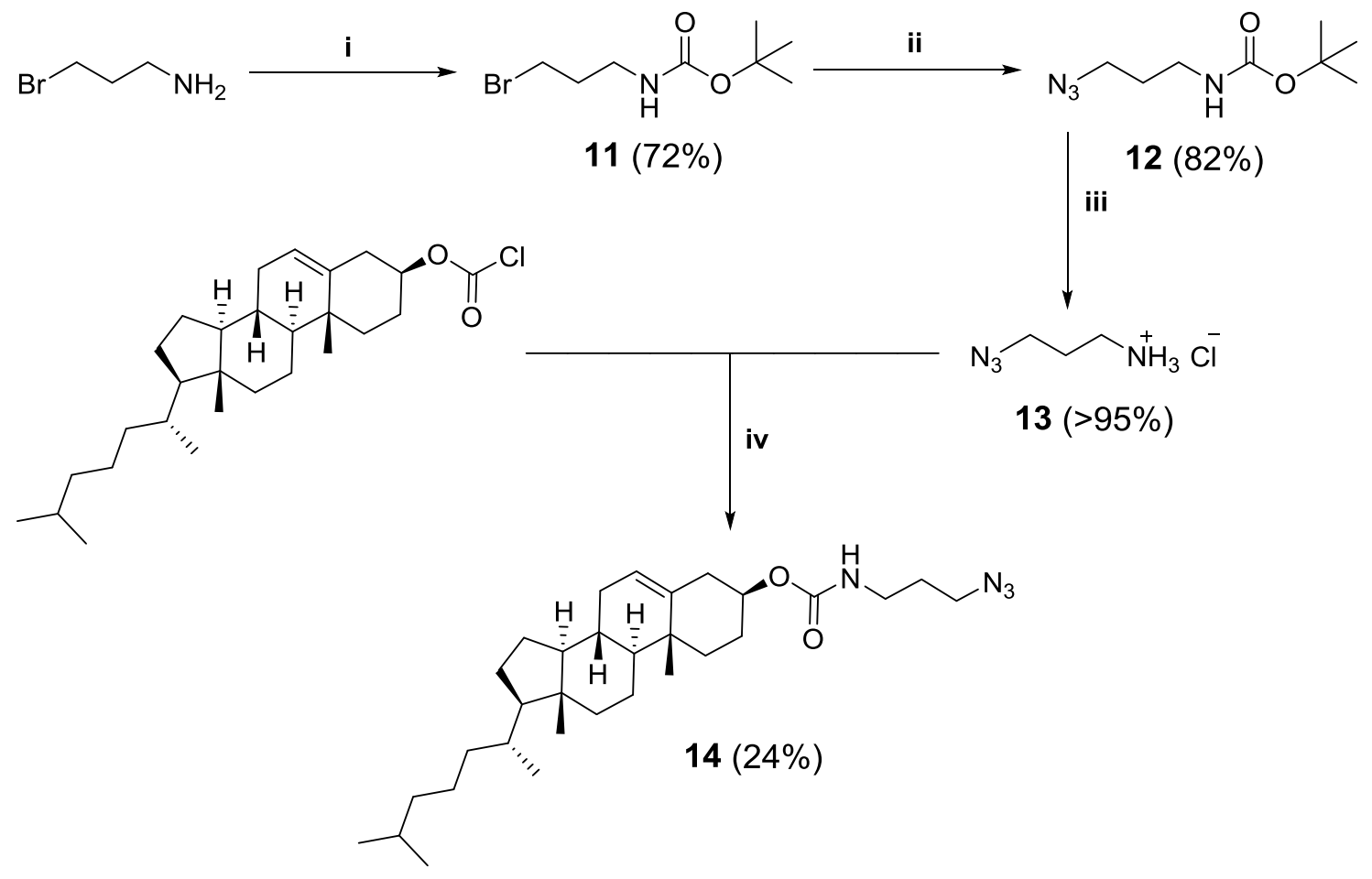

Scheme S4. Synthesis of azide-modified cholesterol 14 incorporating a spacer unit. ${ }^{7}$ 


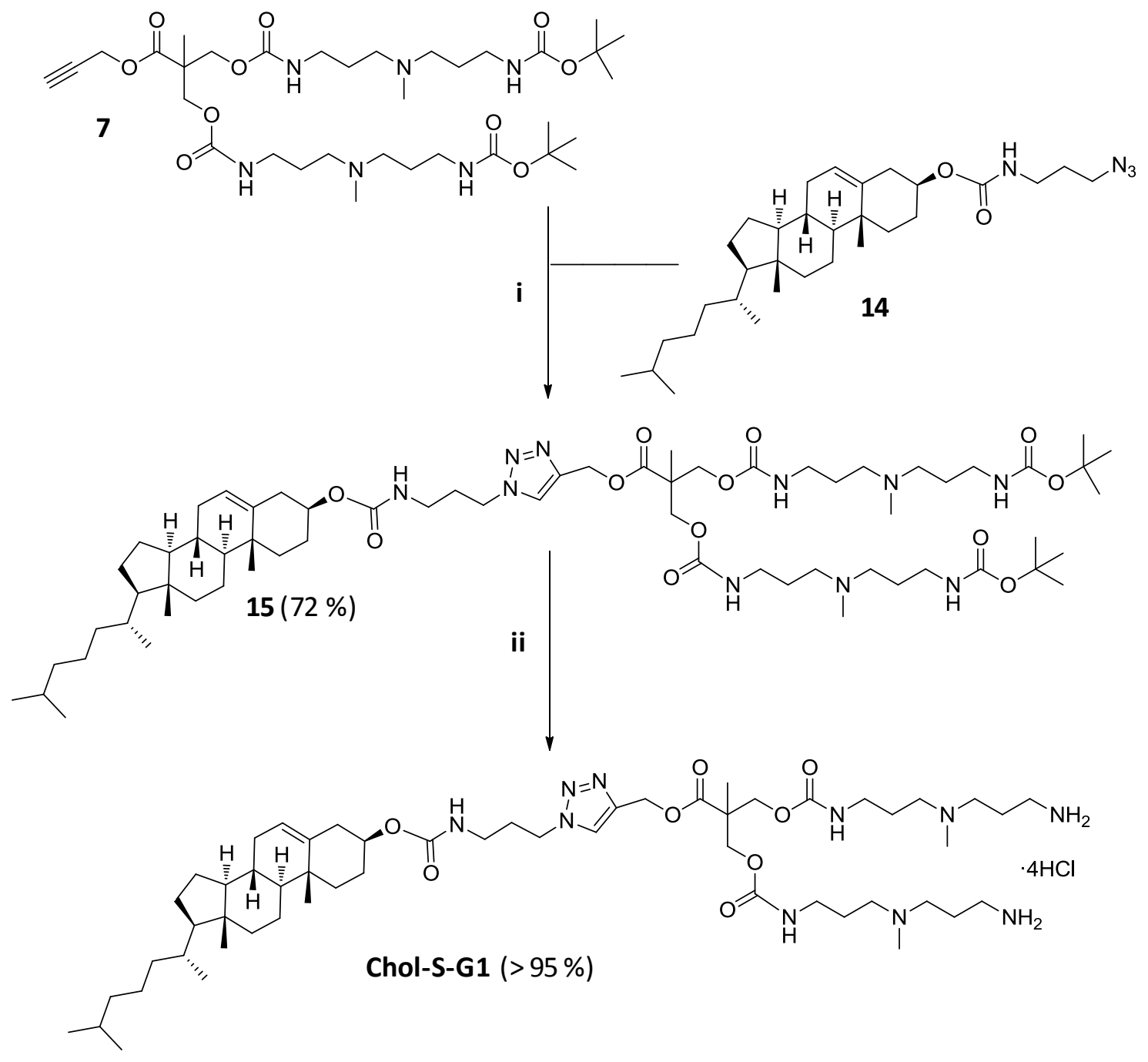

Scheme S5. Synthesis of Chol-S-G1.

Synthesis and Characterisation of Compound 10. Alkyne 7 (190 mg, 0.26 mmol) was dissolved in dry and degassed DMF (10 mL) along with cholesterol azide 9 (120 mg, $0.28 \mathrm{mmol}), \mathrm{CuSO}_{4} \cdot 5 \mathrm{H}_{2} \mathrm{O}(6.5 \mathrm{mg}, 26 \mu \mathrm{mol}, 10 \mathrm{~mol} \%)$ and sodium ascorbate $(10.3 \mathrm{mg}$, $52 \mu \mathrm{mol}, 20 \mathrm{~mol} \%)$. The reaction mixture was stirred for $72 \mathrm{~h}$ at room temperature. The DMF was then removed in vacuo at room temperature and the brown residue was directly purified by GPC (Biobeads SX-1, $\mathrm{CH}_{2} \mathrm{Cl}_{2}$ ) affording the desired product as a colourless solid (100.0 mg, $88 \mu \mathrm{mol}, 37 \%) .{ }^{1} \mathrm{H}$ NMR (400 MHz, $\mathrm{CDCl}_{3}$ ) $\delta$ ppm 7.89 (br s, $\mathrm{CH}$ triazole, $0.15 \mathrm{H}), 7.80$ (br s, $\mathrm{CH}$ triazole, $0.6 \mathrm{H}), 7.64(\mathrm{br} \mathrm{s}, \mathrm{CH}$ triazole, $0.15 \mathrm{H}), 7.48(\mathrm{br}$ s, $\mathrm{CH}$ triazole, $0.1 \mathrm{H}), 5.97(\mathrm{br} \mathrm{s}, \mathrm{NH}, 2 \mathrm{H}), 5.55-5.35\left(\mathrm{~m}, \mathrm{CH}_{2} \mathrm{CHC}, \mathrm{NH}, 3 \mathrm{H}\right), 5.16$ (br s, triazole- $\left.\mathrm{CH}_{2} \mathrm{O}, 2 \mathrm{H}\right), 4.84$ (br s, $\mathrm{CH}$-Ntriazole, $1 \mathrm{H}$ ), 4.11 (br s, $\left.\mathrm{CH}_{2} \mathrm{O}, 4 \mathrm{H}\right), 3.28-2.95$ (m, $\left.\mathrm{CH}_{2} \mathrm{NH}, 8 \mathrm{H}\right), 2.56-2.37\left(\mathrm{~m}, \mathrm{CH}_{2} \mathrm{~N}\left(\mathrm{CH}_{3}\right), 8 \mathrm{H}\right), 2.24$ (br s, $\left.\mathrm{N}\left(\mathrm{CH}_{3}\right), 6 \mathrm{H}\right), 1.97-0.5(\mathrm{~m}$, $\mathrm{CH}_{2} \mathrm{CH}_{2} \mathrm{NH}, \mathrm{C}\left(\mathrm{CH}_{3}\right)_{3}, \mathrm{CH}_{3} \mathrm{C}\left(\mathrm{CH}_{2} \mathrm{O}\right)_{2}, \mathrm{CH}, \mathrm{CH}_{2}, \mathrm{CH}_{3}$ chol, $\left.72 \mathrm{H}\right) .{ }^{13} \mathrm{C} \mathrm{NMR} \mathrm{(101} \mathrm{MHz,} \mathrm{CDCl}_{3}$ ) 
$\delta$ ppm $173.1(C=0), 156.2(C=0), 137.8$ ( $C$ triazole, $\left.\mathrm{CH}_{2} \mathrm{CHC}\right), 124.6\left(\mathrm{CH}_{2} \mathrm{CHC}\right), 123.6(\mathrm{CH}$ triazole)(conf), $78.9\left(\mathrm{C}\left(\mathrm{CH}_{3}\right)_{3}\right), 65.8\left(\mathrm{CH}_{2} \mathrm{O}\right), 63.0\left(\mathrm{CH}_{2} \mathrm{O}\right.$ conf), $60.9\left(\mathrm{CH}_{2} \mathrm{O}\right.$ conf), 58.3 ( $\mathrm{CH}_{2}$-triazole), $56.756 .6\left(\mathrm{CH}_{3} \mathrm{CH}_{2} \mathrm{CH}\right.$ chol), 56.2 (chol $\mathrm{CH}$-triazole), 56.1, 55.3 $\left(\mathrm{CH}_{2} \mathrm{~N}\left(\mathrm{CH}_{3}\right)\right), 53.5,50.0,46.9,42.9$ (quat. $C$ chol conf), 42.8 (quat. $C$ chol conf), 42.7 (quat. $C$ chol conf), 42.3 (quat. $C$ chol), $41.3\left(\mathrm{NC}\left(\mathrm{CH}_{3}\right)\right), 39.5\left(\mathrm{CH}_{2} \mathrm{CH}_{2} \mathrm{NH}\right), 39.5(\mathrm{CH} \mathrm{CH}$ $\mathrm{CH}_{3}$ chol), $38.8\left(\mathrm{CH}_{2} \mathrm{CH}_{2} \mathrm{NH}\right.$ conf $), 37.8,37.1,36.7,36.2,35.8\left(\mathrm{CH}_{2} \mathrm{CH}_{2} \mathrm{NH}\right), 35.4$ ( $\mathrm{CH}_{2} \mathrm{CH}_{2} \mathrm{NH}$ conf), $32.7\left(\mathrm{CH}_{2} \mathrm{CH}_{2} \mathrm{NH}\right)$, 31.9, 31.7, 28.4, 28.2, 28.0, 27.0, 26.7, 26.0, 24.26, 23.9, 23.8, 22.8, 22.7, 22.6, 21.0, 20.6, 19.4, 19.3, 18.7, 17.4, $11.9\left(\mathrm{CH}_{3} \mathrm{CH}_{2} \mathrm{CH}\right.$ chol, $\mathrm{CH}_{3}$ and conf). ESI-MS: Calcd. $[\mathrm{M}+\mathrm{H}]^{+}\left(\mathrm{C}_{61} \mathrm{H}_{108} \mathrm{~N}_{9} \mathrm{O}_{10}\right) \mathrm{m} / \mathrm{z}=1126.8206$; Obs. $[\mathrm{M}+\mathrm{H}]^{+}$ $m / z=1126.8214(\Delta=0.7 \mathrm{ppm})$.

Synthesis and Characterisation of Chol-G1. Boc-protected compound 10 (100.0 mg, $88 \mu \mathrm{mol})$ was dissolved in $\mathrm{MeOH}(30 \mathrm{ml})$ and $\mathrm{HCl}$ gas was bubbled through the solution for $20 \mathrm{~s}$. The reaction mixture was stirred at room temperature for 3 hours. The solvent was removed in vacuo to afford the product as an off-white foam $(80 \mathrm{mg}, 86 \mu \mathrm{mol}$, >95\%). $\quad{ }^{1} \mathrm{H}$ NMR (400 MHz, MeOD) $\delta$ ppm 8.10-8.40 (m, CH triazole conf, 1H), 5.52 (m, $\left.\mathrm{CH}=\mathrm{CCH}_{2}, 1 \mathrm{H}\right), 5.27$ (s, triazole- $\left.\mathrm{CH}_{2}-\mathrm{O}, 2 \mathrm{H}\right), 4.19\left(\mathrm{~m}, \mathrm{CH}\right.$-triazole, $\left.\mathrm{CCH}_{2} \mathrm{O} 5 \mathrm{H}\right), 3.54-3.02$ $\left(\mathrm{m}, \mathrm{CH}_{2} \mathrm{NH}, 16 \mathrm{H}\right), 2.93\left(\mathrm{~s}, \mathrm{CH}_{2} \mathrm{~N}\left(\mathrm{CH}_{3}\right), 6 \mathrm{H}\right), 2.45-0.81(\mathrm{~m}, 189 \mathrm{H}), 0.81-0.58(\mathrm{~m}$, $\mathrm{CH}_{2} \mathrm{CH}_{2} \mathrm{NH}, \mathrm{C}\left(\mathrm{CH}_{3}\right)_{3}, \mathrm{CH}_{3} \mathrm{C}\left(\mathrm{CH}_{2} \mathrm{O}\right)_{2}, \mathrm{CH}, \mathrm{CH}_{2}, \mathrm{CH}_{3}$ chol, 54H). ${ }^{13} \mathrm{C} \mathrm{NMR} \mathrm{(176} \mathrm{MHz,} \mathrm{MeOD)}$ $\delta$ ppm 172.8, 157.0, 137.4, 124.3, 122.9, 78.1, 77.9, 77.7, 72.59, 65.4, 62.0, 61.5, 58.3, $56.9,56.7,56.1,56.1,54.0,52.9,50.1,50.0,48.4,48.1,48.0,47.8,47.7,47.6,47.5$, 47.3 , 47.2, 46.8, 45.1, 42.6, 42.4, 42.0, 39.6, 39.3, 39.2, 37.5, 37.3, 36.7, 36.6, 36.4, $35.9,35.9,35.7,34.8,32.6,31.7,31.6,31.6,27.9,27.7,26.1,24.5,23.9,23.8,23.6$, 23.5, 22.1, 21.8, 21.5, 20.7, 20.3, 18.4, 18.3, 17.8, 17.8, 16.5, 11.1, 10.9. Due to the existence of at least four different conformers the signal assignment for ${ }^{13} \mathrm{C}$ was not possible. ESI-MS: Calcd. $[\mathrm{M}+\mathrm{H}]^{+}\left(\mathrm{C}_{51} \mathrm{H}_{93} \mathrm{~N}_{9} \mathrm{O}_{6}\right) \mathrm{m} / \mathrm{z}=463.8618$; Obs. $[\mathrm{M}+\mathrm{H}]^{+} \mathrm{m} / \mathrm{z}=$ $463.8619(\Delta=0.1 \mathrm{ppm})$.

Synthesis and Characterisation of Compound 15. Alkyne $7(175 \mathrm{mg}, 0.24 \mathrm{mmol})$ was dissolved in dry and degassed DMF (10 mL) along with cholesterol azide 14 (135 mg, $0.26 \mathrm{mmol}$ ), $\mathrm{CuSO}_{4} \cdot 5 \mathrm{H}_{2} \mathrm{O}(5.9 \mathrm{mg}, 24 \mu \mathrm{mol}, 10 \mathrm{~mol} \%)$ and sodium ascorbate $(9.5 \mathrm{mg}, 48$ $\mu \mathrm{mol}, 20 \mathrm{~mol} \%)$. The reaction mixture was stirred for $48 \mathrm{~h}$ at room temperature. The 
DMF was then removed in vacuo at room temperature and the brown residue was directly purified by GPC (DCM) affording the desired product as a colourless solid (232.0 mg, $19 \mu \mathrm{mol}, 79 \%) .{ }^{1} \mathrm{H}$ NMR $\left(400 \mathrm{MHz}, \mathrm{CDCl}_{3}\right) \delta \mathrm{ppm} 7.76$ (br s, $\mathrm{CH}$ triazole, 1H), 6.07 (br s, NHCO, 2H), 5.66-5.00 (m, NHCO, $\mathrm{CH}=\mathrm{CCH}_{2}$, triazole- $\left.\mathrm{CH}_{2} \mathrm{O} 6 \mathrm{H}\right), 4.40(\mathrm{~m}$, $\left(\mathrm{CH}_{2}\right)_{2} \mathrm{CHO}, \mathrm{CH}_{2} \mathrm{CH}_{2}$-triazole, $\left.3 \mathrm{H}\right), 4.13$ (br s, $\left.\mathrm{CCH}_{2} \mathrm{O}, 4 \mathrm{H}\right), 3.04-3.00\left(\mathrm{~m}, \mathrm{CH}_{2} \mathrm{NH}, 10 \mathrm{H}\right)$, 2.79-0.73 (m, $\mathrm{CH}_{2} \mathrm{~N}\left(\mathrm{CH}_{3}\right), \mathrm{CH}_{2} \mathrm{~N}\left(\mathrm{CH}_{3}\right), \mathrm{CH}, \mathrm{CH}_{2}, \mathrm{CH}_{3}$ chol $\left.\mathrm{CH}_{2} \mathrm{CH}_{2} \mathrm{NH}, 85 \mathrm{H}\right), 0.62\left(\mathrm{~s}, \mathrm{CH}_{3}\right.$ chol, 3H). ${ }^{13} \mathrm{C}$ NMR (101 MHz, $\left.\mathrm{CDCl}_{3}\right) \delta$ ppm 193.1 (C=O), $173.1(C=0), 156.6(\mathrm{CONH})$, $156.3(\mathrm{CONH}), 139.7\left(\mathrm{CH}=\mathrm{CCH}_{2} / \mathrm{C}\right.$ triazole $), 124.0(\mathrm{CH}$ triazole $), 122.6\left(\mathrm{CH}_{2} \mathrm{CH}=\mathrm{CCH}_{2}\right)$, $79.0\left(\mathrm{OC}\left(\mathrm{CH}_{3}\right)_{3}\right), 74.5\left(\left(\mathrm{CH}_{2}\right)_{2} \mathrm{CHO}\right), 65.9\left(\mathrm{CCH}_{2} \mathrm{O}\right), 58.3$ (triazole- $\left.\mathrm{CH}_{2}-\mathrm{O}\right), 56.7,56.1$ $\left(\mathrm{CH}, \mathrm{CH}_{3}\right.$ chol), 55.3, $55.5\left(\mathrm{CH}_{2} \mathrm{~N}\left(\mathrm{CH}_{3}\right)\right), 50.0$ ( $\mathrm{CH}$ chol), $47.6\left(\mathrm{CH}_{2} \mathrm{CH}_{2}\right.$-triazole), 47.0 $\left(\mathrm{CCH}_{2} \mathrm{O}\right), 42.3(\mathrm{C}$ chol $), 41.4\left(\mathrm{~N}\left(\mathrm{CH}_{3}\right)\right), 39.7\left(\mathrm{CH}_{2} \mathrm{chol}\right), 39.6\left(\mathrm{CH}_{2} \mathrm{NH}\right), 39.5\left(\mathrm{CH}_{2}\right.$ chol), $38.9\left(\mathrm{CH}_{2} \mathrm{NH}\right), 38.6\left(\mathrm{CH}_{2}\right.$ chol), $37.6\left(\mathrm{CH}_{2} \mathrm{NH}\right), 37.0\left(\mathrm{CH}_{2} \mathrm{chol}\right), 36.6$ (C chol), 36.2, 35.8 , 31.9, $31.9\left(\mathrm{CH}, \mathrm{CH}_{2} \mathrm{CH}_{3} \mathrm{Chol}\right), 30.6\left(\mathrm{CH}_{2} \mathrm{CHNH}\right), 28.5\left(\mathrm{C}\left(\mathrm{CH}_{3}\right)_{3}\right), 28.2,28.2,28.0\left(\mathrm{CH}, \mathrm{CH}_{2}\right.$, $\mathrm{CH}_{3}$ chol), 26.8, $26.1\left(\mathrm{CH}_{2} \mathrm{CHNH}\right), 24.3,23.8,22.8,22.6,21.0,19.3,18.7\left(\mathrm{CH}, \mathrm{CH}_{2}, \mathrm{CH}_{3}\right.$ chol), $17.4\left(\mathrm{CH}_{3} \mathrm{CCH}_{2} \mathrm{O}\right), 11.9\left(\mathrm{CH}_{3}\right.$ chol). ESI-MS: Calcd. $[\mathrm{M}+\mathrm{H}]^{+}\left(\mathrm{C}_{65} \mathrm{H}_{116} \mathrm{~N}_{10} \mathrm{O}_{12}\right) \mathrm{m} / z=$ 614.4354; Obs. $[\mathrm{M}+\mathrm{H}]^{+} \mathrm{m} / \mathrm{z}=614.4382(\Delta=4.5 \mathrm{ppm})$.

Synthesis and Characterisation of Chol-S-G1. Boc-protected compound 15 (100.0 mg, $82 \mu \mathrm{mol})$ was dissolved in $\mathrm{MeOH}(30 \mathrm{ml})$ and $\mathrm{HCl}$ gas was bubbled through the solution for $20 \mathrm{~s}$. The reaction mixture was stirred at room temperature for $3 \mathrm{~h}$. The solvent was removed in vacuo to afford the product as an off-white foam ( $85 \mathrm{mg}, 82 \mu \mathrm{mol},>95 \%$ ). ${ }^{1} \mathrm{H}$ NMR (400 MHz, MeOD) $\delta \mathrm{ppm} 8.10(\mathrm{~s}, \mathrm{CH}$ triazole, $1 \mathrm{H}), 5.42-5.32\left(\mathrm{~m}, \mathrm{CH}=\mathrm{CCH}_{2}, 1 \mathrm{H}\right)$, $5.23\left(\mathrm{~s}\right.$, triazole- $\left.\mathrm{CH}_{2}-\mathrm{O}, 2 \mathrm{H}\right), 4.44\left(\mathrm{t}, \mathrm{J}=6.8 \mathrm{~Hz}, \mathrm{CH}_{2} \mathrm{CH}_{2}\right.$-triazole , $\left.2 \mathrm{H}\right), 4.39-4.26(\mathrm{~m}$, $\left.\left(\mathrm{CH}_{2}\right)_{2} \mathrm{CHO}, 1 \mathrm{H}\right), 4.16\left(\mathrm{~s}, \mathrm{CCH}_{2} \mathrm{O}, 4 \mathrm{H}\right), 3.46-3.01\left(\mathrm{~m}, \mathrm{CH}_{2} \mathrm{NH}, \mathrm{CH}_{2} \mathrm{~N}\left(\mathrm{CH}_{3}\right) 18 \mathrm{H}\right), 2.98-2.78(\mathrm{~s}$, $\left.\mathrm{CH}_{2} \mathrm{~N}\left(\mathrm{CH}_{3}\right), 6 \mathrm{H}\right), 2.40-0.79\left(\mathrm{~m}, \mathrm{CH}, \mathrm{CH}_{2}, \mathrm{CH}_{3}\right.$ chol $\left.\mathrm{CH}_{2} \mathrm{CH}_{2} \mathrm{NH} 53 \mathrm{H}\right), 0.70$ (s, $\mathrm{CH}_{3}$ chol, $3 \mathrm{H}$ ). ${ }^{13} \mathrm{C}$ NMR (101 MHz, MeOD) $\delta$ ppm $194.4(C=0), 174.2$ (C=O), 158.4 (CONH), 141.1 $\left(\mathrm{CH}=\mathrm{CCH}_{2} / \mathrm{C}\right.$ triazole $), 127.1(\mathrm{CH}$ triazole $), 123.4\left(\mathrm{CH}_{2} \mathrm{CH}=\mathrm{CCH}_{2}\right), 75.5\left(\left(\mathrm{CH}_{2}\right)_{2} \mathrm{CHO}\right), 66.9$ $\left(\mathrm{CCH}_{2} \mathrm{O}\right), 58.8$ (triazole- $\left.\mathrm{CH}_{2}-\mathrm{O}\right), 58.0,57.5\left(\mathrm{CH}\right.$ chol), 55.5, $54.4\left(\mathrm{CH}_{2} \mathrm{~N}\left(\mathrm{CH}_{3}\right)\right), 51.5(\mathrm{CH}$

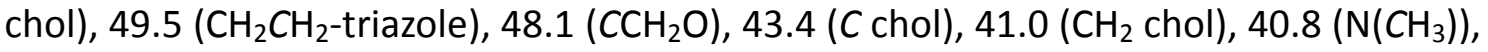
$40.6\left(\mathrm{CH}_{2}\right.$ chol), 39.6, $38.7\left(\mathrm{CH}_{2} \mathrm{NH}\right), 38.2\left(\mathrm{CH}_{2}\right.$ chol), $38.1\left(\mathrm{CH}_{2} \mathrm{NH}\right), 37.6$ (C chol), 37.3, 37.0, 33.1, 32.9, 31.4, 29.2, 29.2, 29.0, 25.8, 25.2, 24.9, 23.5, 23.2, 22.9, 22.1, 19.8, $19.2\left(\mathrm{CH}_{2} \mathrm{CHNH}, \mathrm{CH} \mathrm{CH} \mathrm{CH}_{3}\right.$ chol), $17.9\left(\mathrm{CH}_{3} \mathrm{CCH}_{2} \mathrm{O}\right), 12.3\left(\mathrm{CH}_{3}\right.$ chol). ESI-MS: Calcd. 
$[\mathrm{M}+\mathrm{H}]^{+}\left(\mathrm{C}_{55} \mathrm{H}_{99} \mathrm{~N}_{10} \mathrm{O}_{8}\right) \mathrm{m} / \mathrm{z}=1027.7652 ;$ Obs. $[\mathrm{M}+\mathrm{H}]^{+} \mathrm{m} / \mathrm{z}=1027.7642(\Delta=-0.1 \mathrm{ppm})$.

\section{$3 \quad$ Nile Red Assay}

A 2.5 mM Nile Red stock solution was made in EtOH. A binder stock solution was made up in PBS buffer at various concentrations depending on the starting concentration for the assay. Aliquots of the stock solution were taken and diluted with PBS to the desired concentration in a $1 \mathrm{ml}$ assay volume. Nile red $(1 \mu \mathrm{l})$ was added and the fluorescence emission was measured using an excitation wavelength of $550 \mathrm{~nm}$. Fluorescence intensity was recorded at $635 \mathrm{~nm}$.
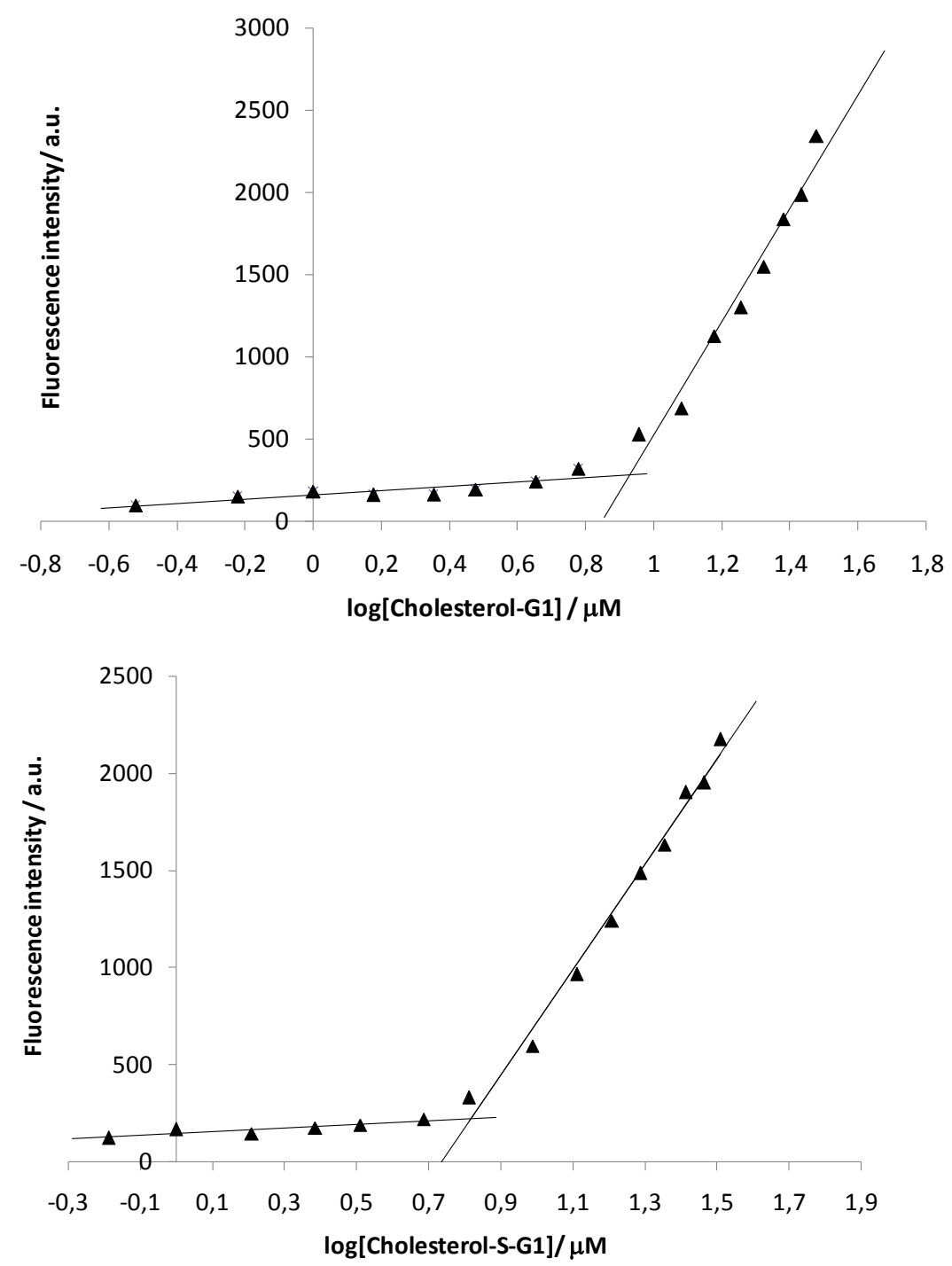

Figure S1. Fluorescence intensity of Nile Red in the presence of increasing amounts of 
Chol-G1 and Chol-S-G1.

\section{Transmission Electron Microscopy}

Studies were performed on a FEI Technai 12 Biotwin operated at $120 \mathrm{kV} .10 \mu \mathrm{l}$ of sample solution, in $\mathrm{H}_{2} \mathrm{O}$ was placed on a standard copper grid with Formvar and a carbon support film and allowed to set for three minutes. The grid was then stained with $1 \%$ uranyl acetate while wet, allowing the stain to run across the grid ( $1 \%$ in water, $\mathrm{pH}$ 4.5). The grids were allowed to rest for ten minutes before being imaged.
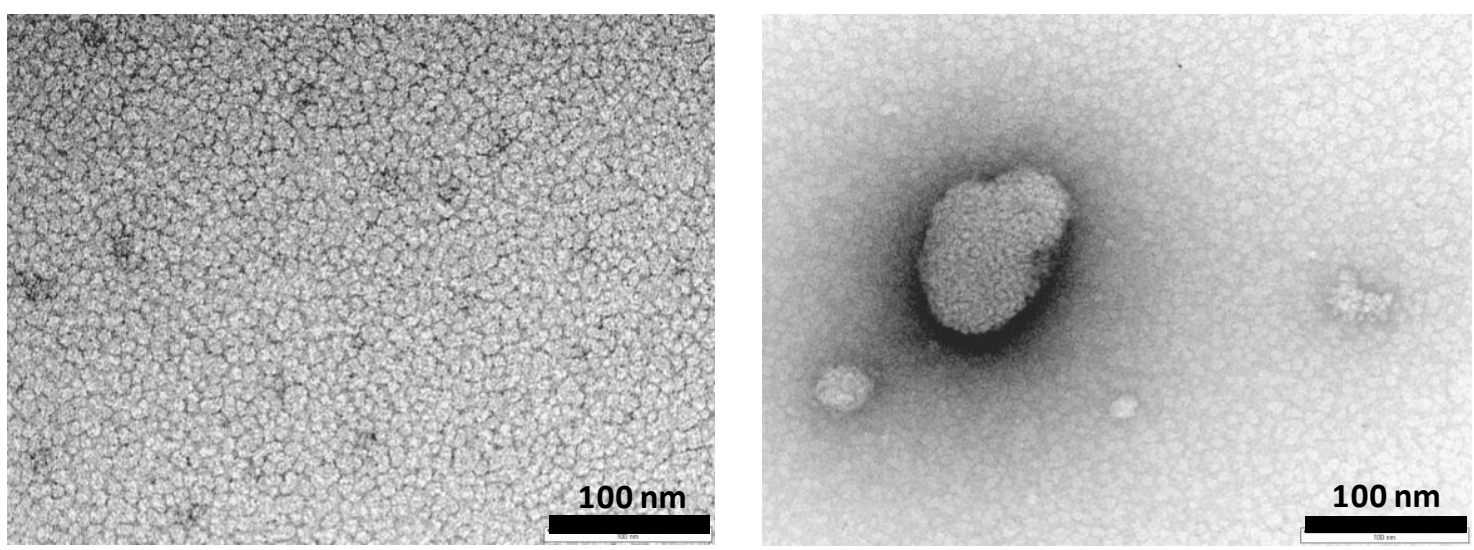

Figure S2. Left: TEM image of Chol-G1 dried from aqueous solution indicating the formation of self-assembled micellar nanostructures. Right: TEM image of Chol-G1 in the presence of heparin dried from aqueous solution indicating the formation of self-assembled micelles that form close packed hierarchically organised nanoscale aggregates.

\section{$5 \quad$ Mallard Blue Assay}

In buffer. A cuvette containing $2 \mathrm{~mL}$ of MalB $(25 \mu \mathrm{M})$, heparin $(27 \mu \mathrm{M})$ and $\mathrm{NaCl}(150$ $\mathrm{mM})$ in Tris $\mathrm{HCl}(10 \mathrm{mM})$ was titrated with binder stock solution to give the cuvette a suitable binder-heparin charge ratio. The binder stock solution was composed of the 
original MalB/heparin/ $\mathrm{NaCl} /$ Tris $\mathrm{HCl}$ stock solution endowed additionally with a concentration of binder such that, after addition of $10 \mu \mathrm{L}$ binder stock, the cuvette charge ratio (+ : -$)$ is 0.1 . After each addition, the cuvette was inverted to ensure good mixing and the absorbance at $615 \mathrm{~nm}$ was recorded against a Tris $\mathrm{HCl}(10 \mathrm{mM})$ baseline. A normalisation range for absorption was set against a solution of MalB $(25 \mu \mathrm{M}), \mathrm{NaCl}$ $(150 \mathrm{mM})$ in Tris $\mathrm{HCl}(10 \mathrm{mM})$ and one containing MalB $(25 \mu \mathrm{M})$, heparin $(27 \mu \mathrm{M}), \mathrm{NaCl}$ (150 mM) in Tris $\mathrm{HCl}(10 \mathrm{mM})$.

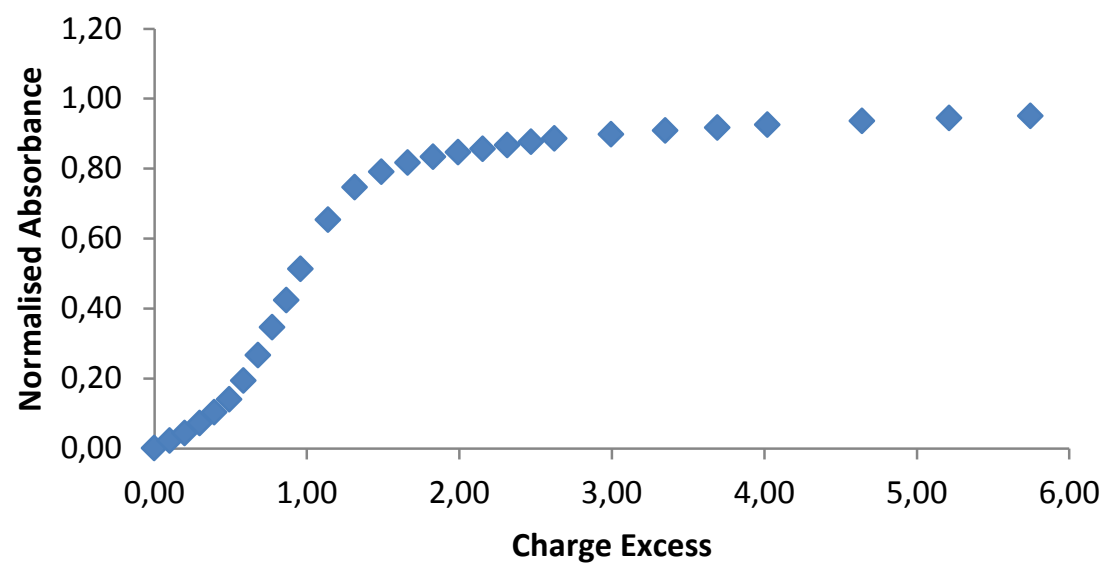

Figure S3. Mallard Blue assay for Chol-G1 in buffer.

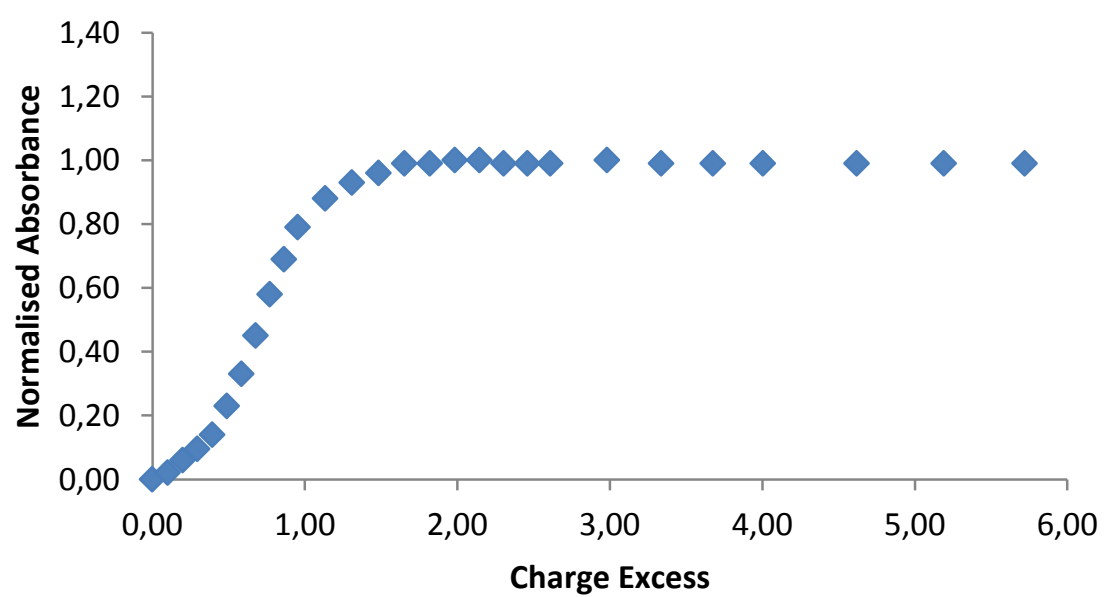

Figure S4. Mallard Blue assay for Chol-S-G1 in buffer.

In serum. Fourteen cuvettes were charged with $1.75 \mathrm{~mL}$ of MalB $(28.53 \mu \mathrm{M})$ in Tris $\mathrm{HCl}(10 \mathrm{mM})$ and a volume of binder stock solution to give the cuvette a suitable binder-heparin charge ratio. The binder stock solution was additionally endowed with 
its own MalB $(25 \mu \mathrm{M})$, heparin $(27 \mu \mathrm{M})$ and Tris $\mathrm{HCl}(10 \mathrm{mM})$ concentrations. The concentration of binder in the binder stock was determined in the same manner described for the heparin displacement assay in buffer. Separately, a heparin (216 $\mu \mathrm{M})$ solution was made in $100 \%$ human serum. Sequentially, each cuvette was titrated with $0.25 \mathrm{~mL}$ of the heparin-in-serum solution and inverted to ensure thorough mixing. The absorbance was recorded at $615 \mathrm{~nm}$ against a baseline of $(1.75 \mathrm{~mL} 10 \mathrm{mM}$ Tris $\mathrm{HCl}$, $0.25 \mathrm{~mL}$ 100\% Human Serum) and a normalisation range for absorption was set against a solution containing exclusively MalB $(25 \mu \mathrm{M})$ and one containing MalB $(25 \mu \mathrm{M})$ and heparin $(27 \mu \mathrm{M})$.

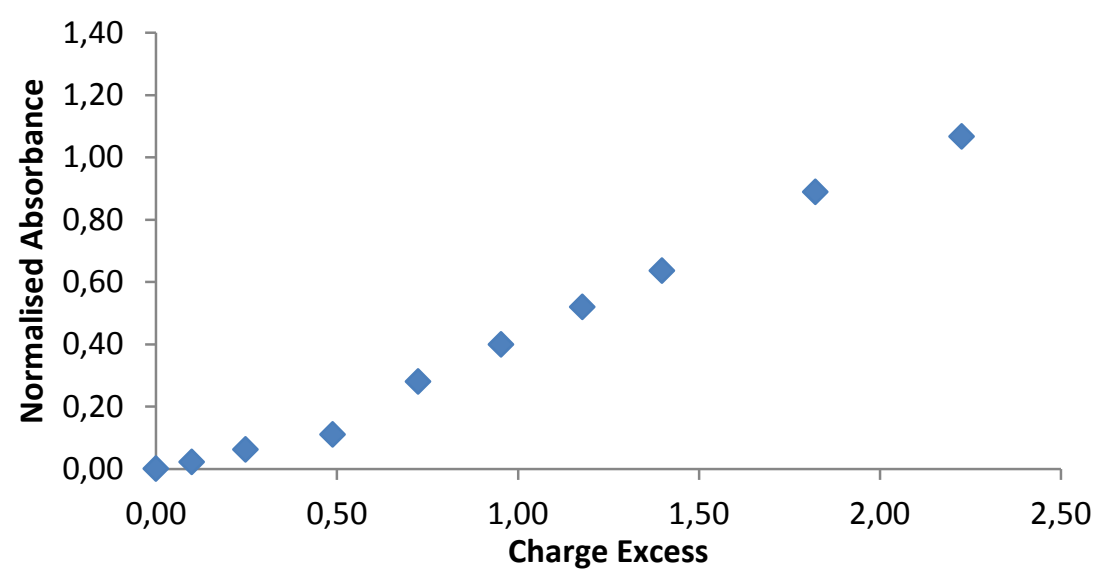

Figure S5. Mallard Blue assay for Chol-G1 in serum. As the loading of heparin is increased, some precipitation was observed which increased the apparent absorbance, giving normalised values $>1.0$ at the end of the experiment. This did not affect the determination of $\mathrm{CE}_{50}$, as no precipitation was observed at charge excesses $\leq 1.5$.

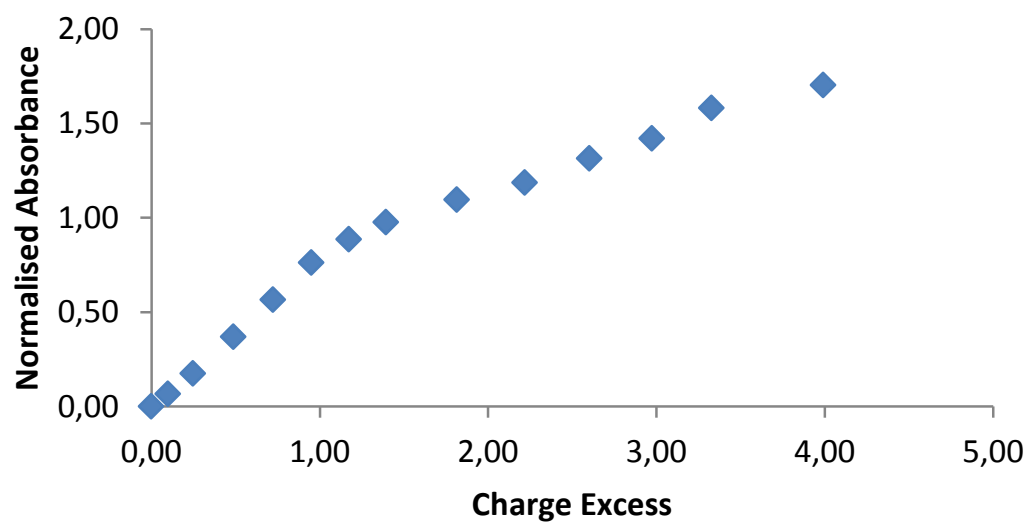

Figure S6. Mallard Blue assay for Chol-S-G1 in serum. As the loading of heparin is 
increased, some precipitation was observed which increased the apparent absorbance, giving normalised values $>1.0$ at the end of the experiment. This did not affect the determination of the $\mathrm{CE}_{50}$, as no precipitation was observed at charge excesses $\leq 1.0$.

\section{Isothermal Calorimetry}

ITC experiments were performed with a MicroCal PEAQ-ITC calorimeter (Malvern, UK) at $25^{\circ} \mathrm{C}$. The cell volume was $208 \mu \mathrm{L}$. All experiments were conducted by step-by-step injections of a constant volume of concentrated Chol-S-G1 or $\mathbf{C}_{\mathbf{2 2}}$-G1 SAMul solutions into the calorimetric cell containing Tris $\mathrm{HCl}$ buffer $(10 \mathrm{mM})$, or buffered solutions of heparin, respectively. Specifically, for CAC determination, a constant $1 \mu \mathrm{L}$ portion of each SAMul solutions $(250 \mu \mathrm{M})$ were injected 37 times into the reaction cell at $210 \mathrm{~s}$ intervals. Figure S7 shows the result for CAC determination of compound Chol-S-G1 in buffer solution as an example. The CAC is defined as the midpoint of the $\mathrm{Q}$ vs. $\mathrm{C}$ curve in Figures S6. For a precise determination of the midpoint of the process, first $\mathrm{Q}$ vs $C$ data were fitted to a suitable model and then the first derivative of the $Q$ vs $C$ fitting curve was calculated (Figure S7, insert). The CAC corresponds to the minimum of the derivative curve, as highlighted by the arrow in the insert of Figure S7.

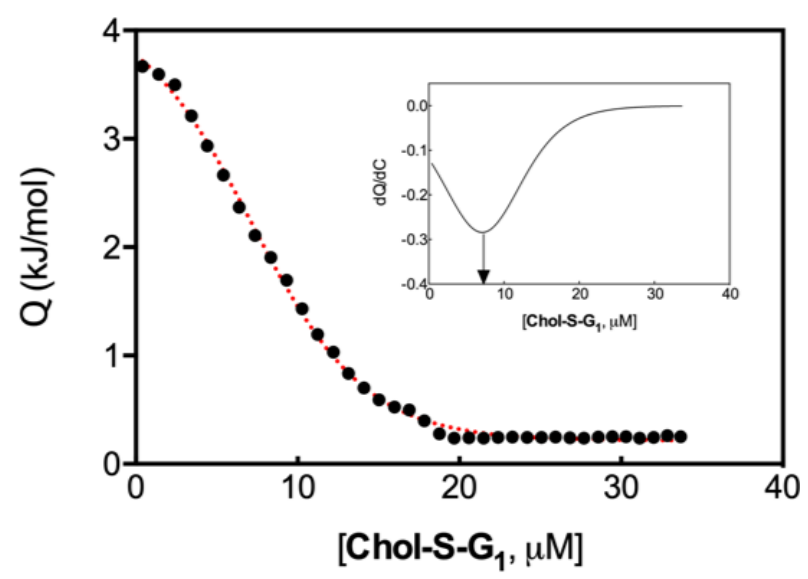

Figure S7. Heat observed on each injection vs. final Chol-S-G1 concentration in the calorimetric cell. Symbols: experimental data; dotted red line: Boltzmann fit $\left(R^{2}=0.99\right)$. 
Insert: The first derivative of the curve in the principal figure (in arbitrary units). The CAC is taken as the $x$-value at the minimum of $d Q / d C$ curve (indicated by the arrow).

For heparin binding, a series of SAMul solutions $(4 \mathrm{mM})$ were injected in 37 portions of $1 \mu \mathrm{L}$ at $210 \mathrm{~s}$ intervals, such that the concentration of Chol-S-G1 or $\mathbf{C}_{\mathbf{2 2}}$ - $\mathbf{G 1}$ was always above the CAC, allowing us to assume that the micelles remained intact throughout the experiment. The polyanion concentration in the calorimeter cell was $250 \mu \mathrm{M}$. For the experiments in the presence of Human Serum Albumin (HSA), the $4 \mathrm{mM}$ buffered solution of Chol-S-G1 or $\mathbf{C}_{\mathbf{2 2}}$-G1 was preincubated for $1 \mathrm{~h}$ with $500 \mu \mathrm{M}$ of HSA. All solutions were degassed for $30 \mathrm{~min}$ at room temperature under stirring at $500 \mathrm{rpm}$ prior to each experiment. After careful washing, the cell was pre-rinsed with a portion of the buffer or heparin solutions, respectively. On filling the cell and syringe, stirring was turned and each system was allowed to thermally equilibrate for 30 minutes. During heparin/SAMul binding experiments, when all binding sites were occupied, only a heat signal resulting from mixing, dilution effects and liquid friction was observed. The values of these unspecific heats were further confirmed by control experiments (data not shown); accordingly, they were subtracted from the relevant data set to yield the corrected integrated data of Figure 4. All experiments were run in triplicate.

\section{Degradation Assay}

The binder was dissolved $(200 \mu \mathrm{M})$ in ammonium bicarbonate $(10 \mathrm{mM}, \mathrm{pH}=7.5) .250$ $\mu \mathrm{L}$ of this binder solution was combined with $250 \mu \mathrm{L}$ of Gly-Ala standard ( $1 \mathrm{mM}$, in 10 $\mathrm{mM}$ ammonium bicarbonate) for mass spectrometric analysis. Following incubation of the binder solution for 24 hours and 72 hours at $25^{\circ} \mathrm{C}$, the same analysis was repeated. 

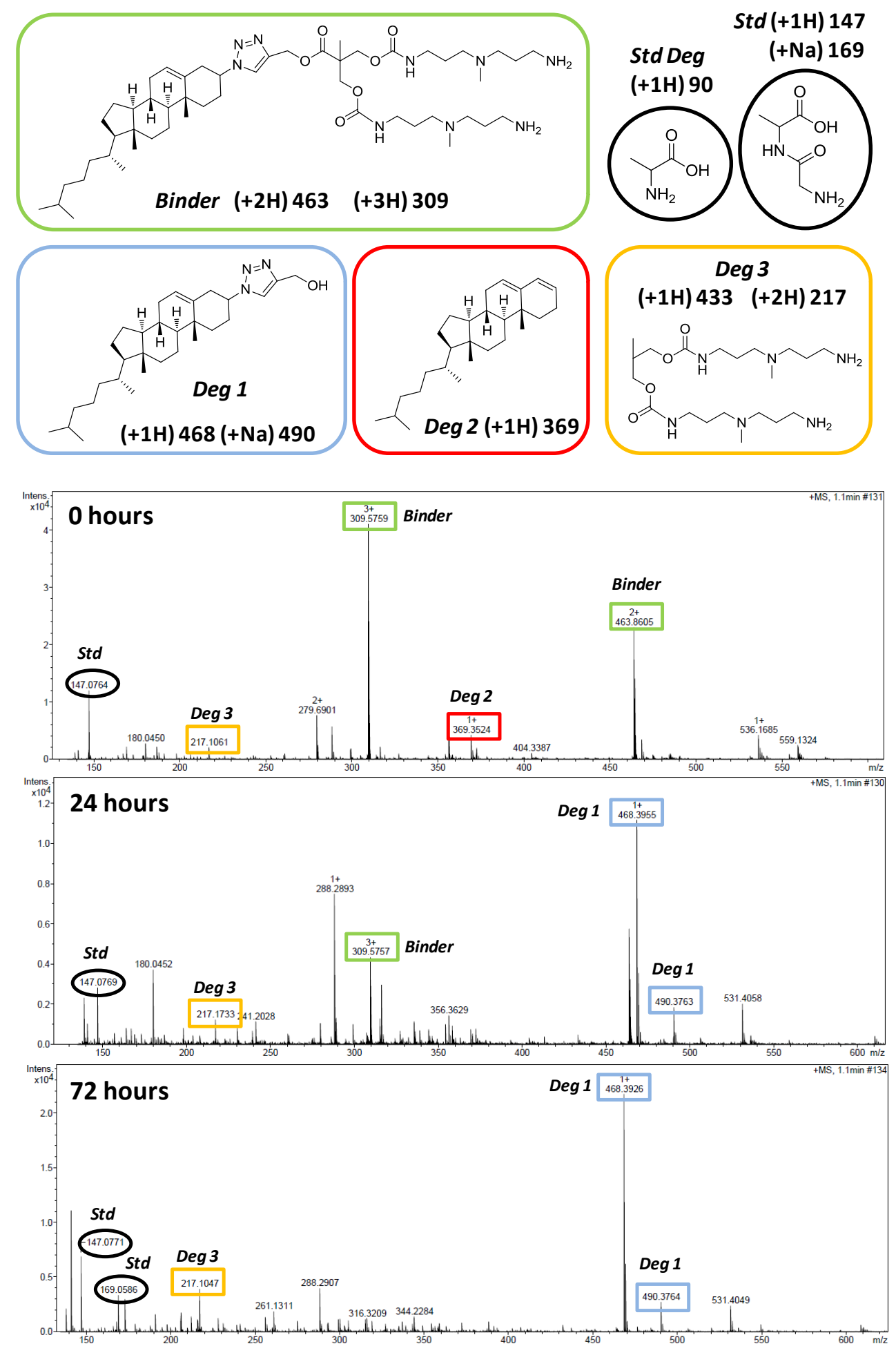

Figure S8. Structures of compounds and degradation products and masses of resulting ions. Mass spectra of Chol-S-G1 at the start of the assay and after incubatuon at $25^{\circ} \mathrm{C}$ for $24 \mathrm{~h}$ and $72 \mathrm{~h}$, respectively. 
For the fluorescence degradation study the binder was dissolved in phosphate buffer saline (PBS, $0.01 \mathrm{M}$, endowed with $\mathrm{NaCl}(138 \mathrm{mM})$ and $\mathrm{KCl}(2.7 \mathrm{mM}))$ at a concentration of $25 \mu \mathrm{M}$. In a fluorescence cuvette, an aliquot $(1 \mathrm{~mL})$ of this solution was mixed with a small amount of Nile Red $(1 \mu \mathrm{L}, 2.5 \mathrm{mM}$ in ethanol). Fluorescence intensity at $635 \mathrm{~nm}$ was recorded using $550 \mathrm{~nm}$ excitation wavelength. The binder stock solution was incubated at 25 and $37^{\circ} \mathrm{C}$ for $24 \mathrm{~h}$ before another aliquot was taken for fluorescence measurements as before. In the time resolved experiment, the initial solution was left in the fluorimeter and the emission was monitored at regular periods of time at $25^{\circ} \mathrm{C}$.

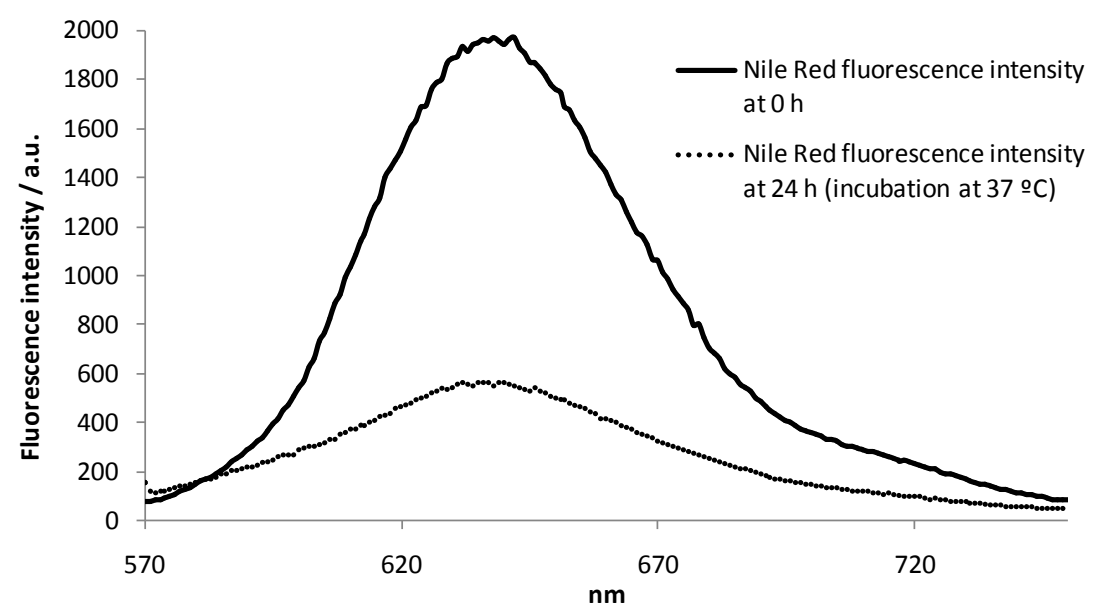

Figure S9. Fluorescence intensity of Nile Red at time $0 \mathrm{~h}$ and $24 \mathrm{~h}$ demonstrating degradation of Chol-S-G1 and disassembly of micelles. Incubation at $37^{\circ} \mathrm{C}$

\section{Computational Simulation of Micelle Stability}

Each SAMul monomer was parametrized according to a well-established procedure. ${ }^{8}$ Partial charges were derived by the RESP procedure implemented in the RED server, ${ }^{9}$ while Gaff atom types were assigned with the Antechamber ${ }^{10}$ of AmberTools18. The Chol-S-G1 and C22-G1 micelles were built and optimized according to our multiscale simulation procedure described in details in our previous work. ${ }^{7,11,12}$ Accordingly, the relevant micelle aggregation numbers were $N_{\text {agg }}=24 \pm 1$ and $23 \pm 1$ for C22-G1 and 
Chol-S-G1, respectively; the corresponding micellar diameters were $9.3 \pm 0.1 \mathrm{~nm}$ and $8.7 \pm 0.2 \mathrm{~nm} \mathrm{C22-G1}$ and Chol-S-G1, respectively. Each micelle was solvated with an appropriate number of $\mathrm{TIP} \mathrm{P}^{13}$ water molecules extending at least $20 \AA$ from the solute. Sodium and chloride ions were added to neutralize the systems and to reach a physiological concentration of $0.15 \mathrm{M}$. Each system was next minimized by a combination of steepest descent (50000 cycles) and conjugate gradient (50000 cycles), followed by a heating phase of 100 ps in the constant volume-constant temperature $(\mathrm{NVT})$ ensemble (integration step $=1 \mathrm{fs}$ ). Then, $10 \mathrm{~ns}$ of system equilibration under isobaric-isothermal (NPT) conditions were performed (integration step $=2 \mathrm{fs}$ ), while pressure was maintained by the Berendsen ${ }^{14}$ barostat. Simulations were prolonged for further 200 ns switching to Monte Carlo barostat implemented in Amber (2 fs time step, $\mathrm{T}=25^{\circ} \mathrm{C}, \mathrm{P}=1 \mathrm{bar}$ ). Temperature was controlled by the Langevin method (damping coefficient of $5 \mathrm{ps}^{-1}$ ) throughout all the MD simulations. Electrostatic interactions were computed by means of the PME algorithm. All MD simulations were carried out using the AMBER $18^{15}$ platform running on our CPU/GPU hybrid cluster. Finally, constant-force steered molecular dynamic simulations (CF-SMD) were performed starting from one equilibrated micelle of each monomer (see main text for details).

\section{Cell Viability Assay}

Human hepatoblastoma cells (Hep3B, ATCC HB-8064) were cultured in Minimum Essential Medium (MEM) supplemented with $1 \mathrm{mM}$ non-essential amino acids, $2 \mathrm{mM}$ L-glutamine, $1 \mathrm{mM}$ sodium pyruvate, 10\% heat-inactivated fetal bovine serum (FBS), penicillin $(50 \mathrm{U} / \mathrm{mL})$ and streptomycin $(50 \mu \mathrm{g} / \mathrm{mL})$. Cell cultures were maintained in an incubator (Memmert, Schwabach, Germany) at $37^{\circ} \mathrm{C}$ in a humidified atmosphere of $5 \%$ $\mathrm{CO}_{2} / 95 \%$ air (Praxair, Valencia, Spain). Cellular viability was assessed by the MTT [3-(4,5-dimethylthiazol-2-yl)-2,5-diprenyl tetrazolium bromide] assay, which is a colorimetric assay based on the ability of cells to reduce a soluble yellow tetrazolium 
salt to blue formazan crystals. For the treatment, cells seeded in 96-well plates (15000 cells/well) and allowed to proliferate exponentially. Two types of treatment were performed: i) 3 h-exposure to the chemical reagent in complete MEM without FBS, followed by a $21 \mathrm{~h}$-recovery for which the medium was replaced with FBS-containing MEM and ii) 24 h-treatment in complete MEM with FBS. In both cases, MTT reagent (Roche Diagnostics, Mannheim, Germany) was added (20 $\mu \mathrm{L} /$ well) for the last $4 \mathrm{~h}$ of the incubation period after which cells were dissolved in DMSO (100 $\mu \mathrm{L} /$ well, 5 min, 37 ${ }^{\circ} \mathrm{C}$ ) and absorbance was detected at $570 \mathrm{~nm}$ using a plate-reader spectrophotometer (Multiscan FC, Thermo Scientific, Rockford, IL, USA). 
10 NMR Spectra

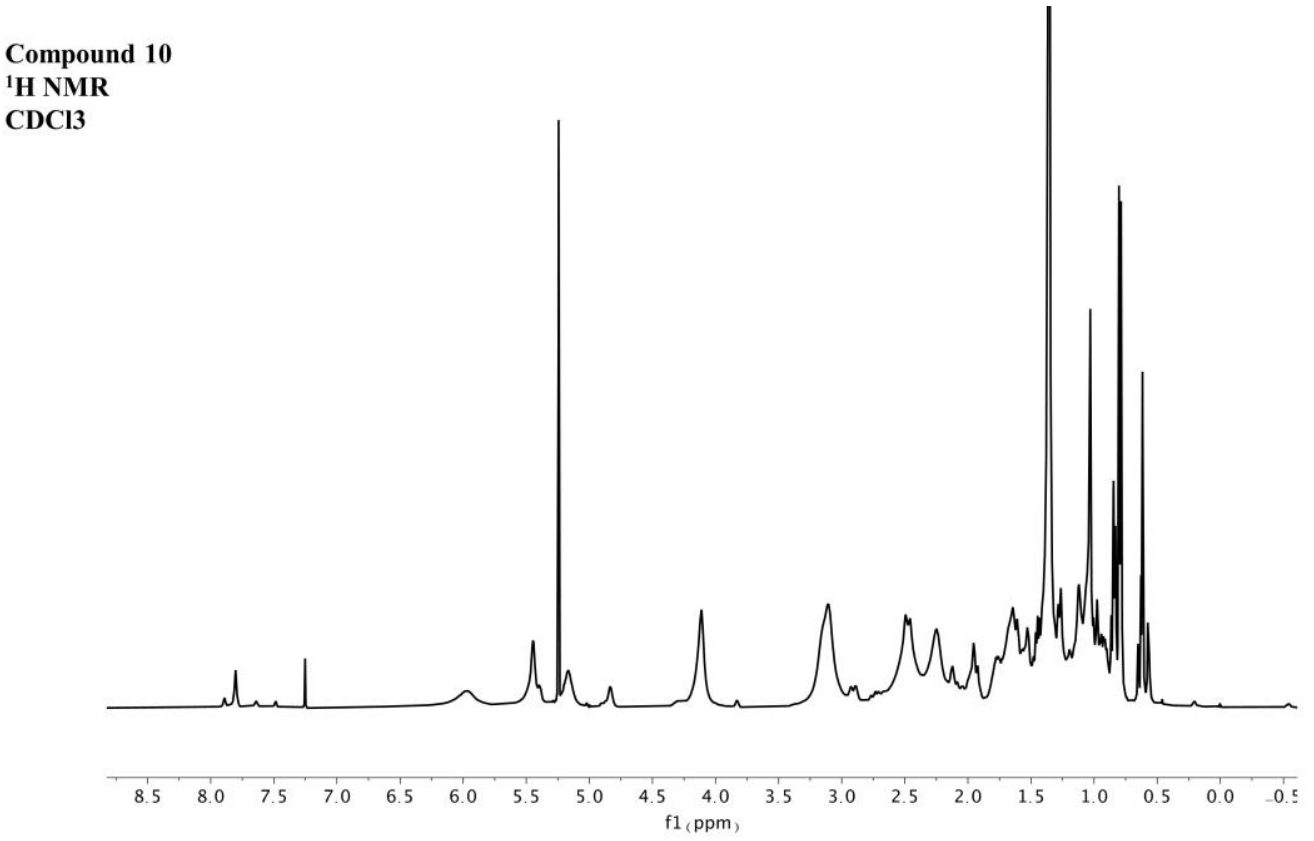

Figure S10. ${ }^{1} \mathrm{H}$ NMR spectrum of compound 10 in $\mathrm{CDCl}_{3}$.

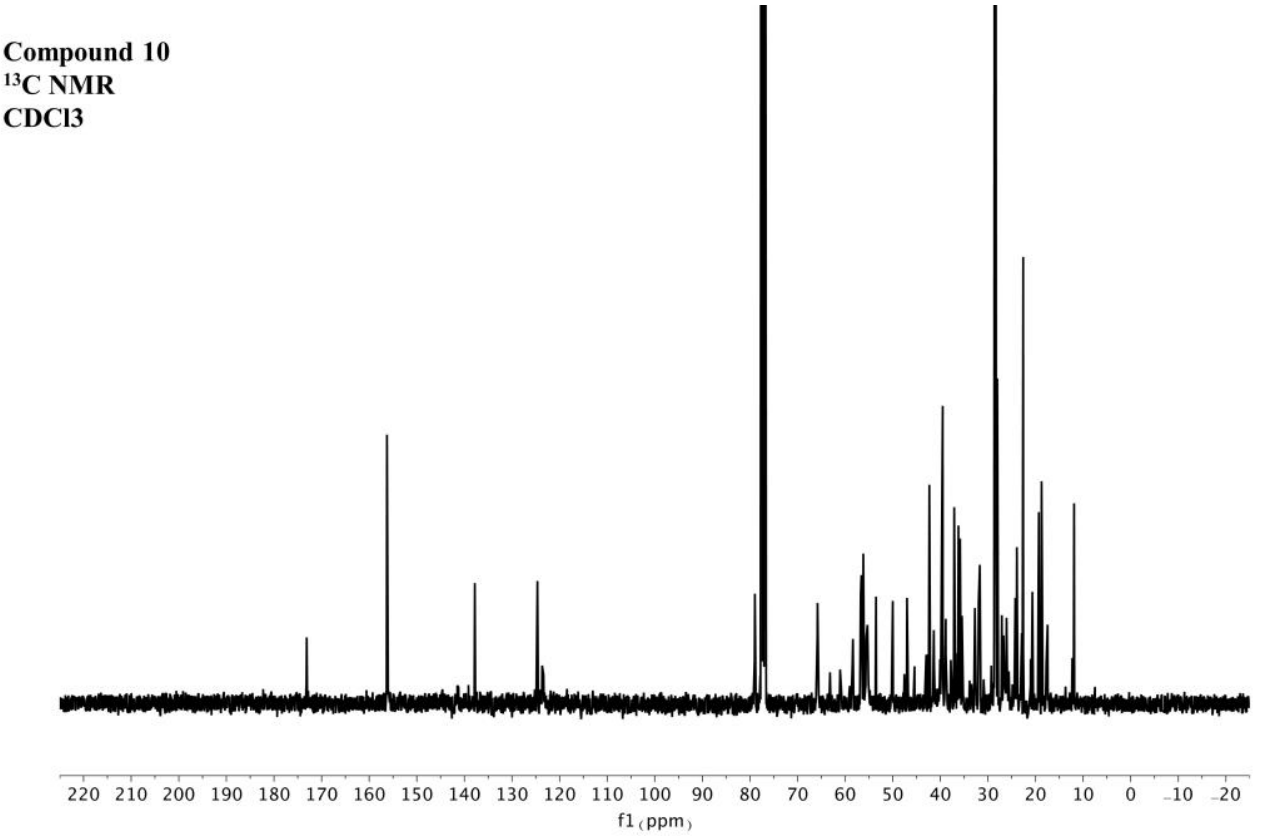

Figure S11. ${ }^{13} \mathrm{C}$ NMR spectrum of compound 10 in $\mathrm{CDCl}_{3}$. 
Compound Chol-G1

${ }^{13}$ C NMR

MeOD

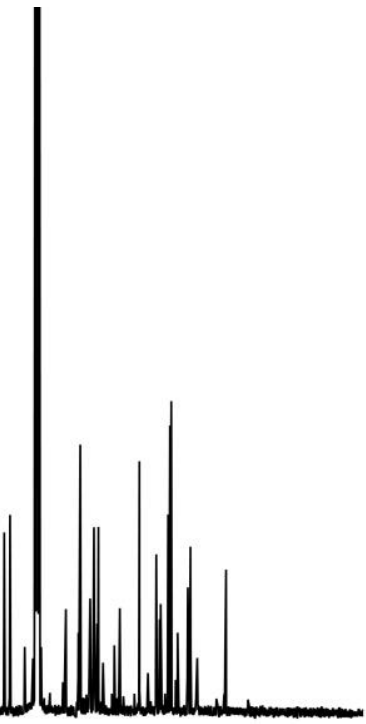

\begin{tabular}{lllllllllllllllllllllllllll}
\hline 210 & 200 & 190 & 180 & 170 & 160 & 150 & 140 & 130 & 120 & 110 & 100 & 90 & 80 & 70 & 60 & 50 & 40 & 30 & 20 & 10 & 0 & -10 \\
$\mathrm{f} 1(\mathrm{ppm})$ & & &
\end{tabular}

Figure S12. ${ }^{1} \mathrm{H}$ NMR spectrum of Chol-G1 in $\mathrm{CD}_{3} \mathrm{OD}$.

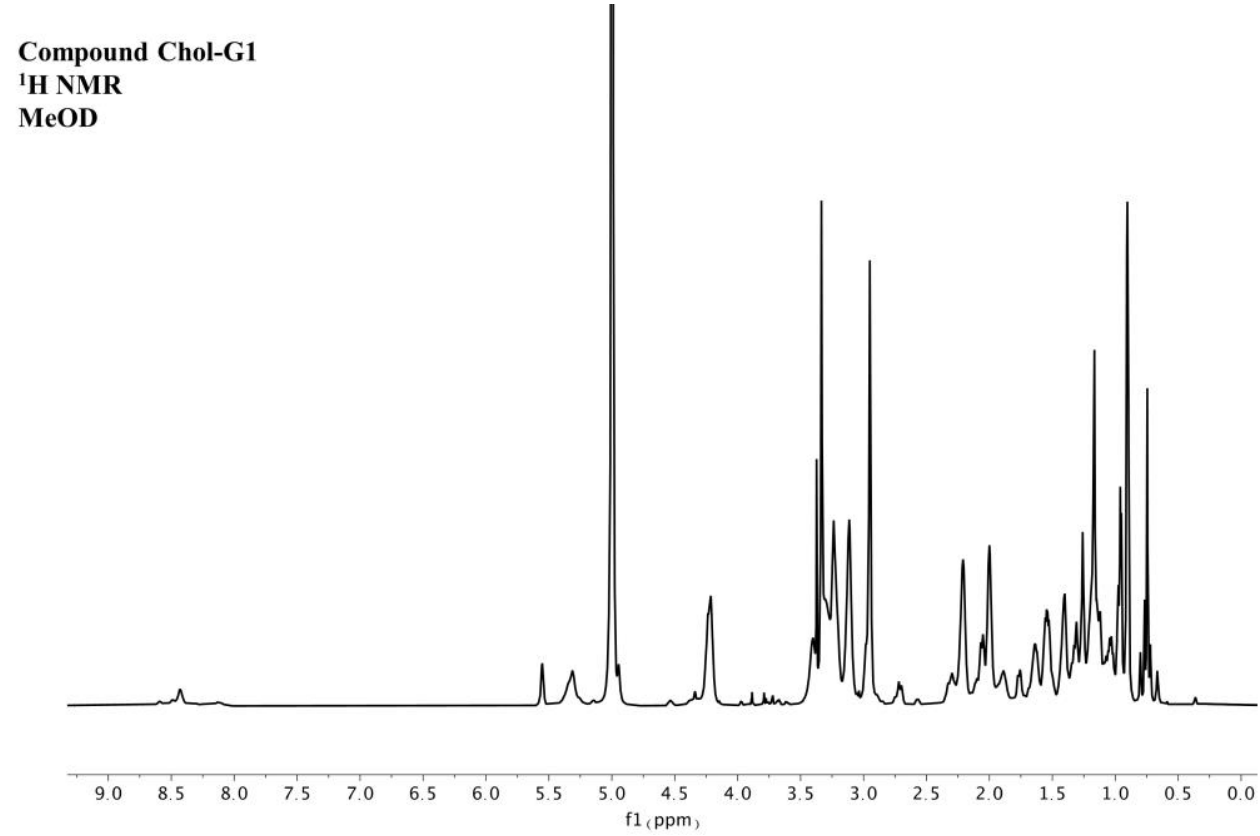

Figure S13. ${ }^{13} \mathrm{C}$ NMR spectrum of Chol-G1 in $\mathrm{CD}_{3} \mathrm{OD}$. 
Compound 15

${ }^{1}$ H NMR

CDCl3

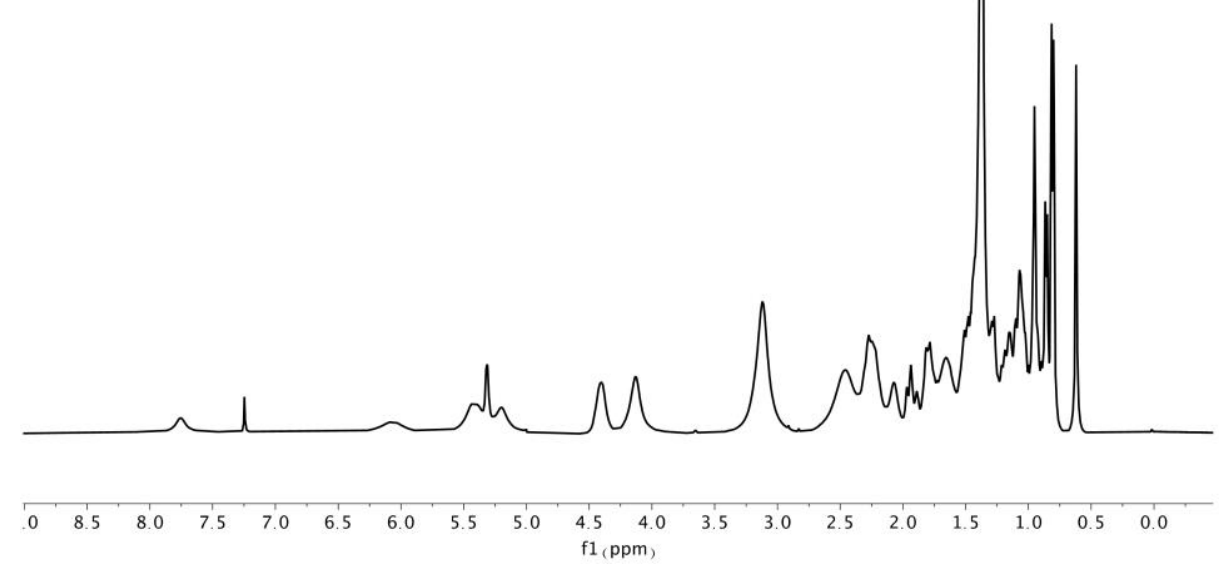

Figure S14. ${ }^{1} \mathrm{H}$ NMR spectrum of compound 15 in $\mathrm{CDCl}_{3}$.

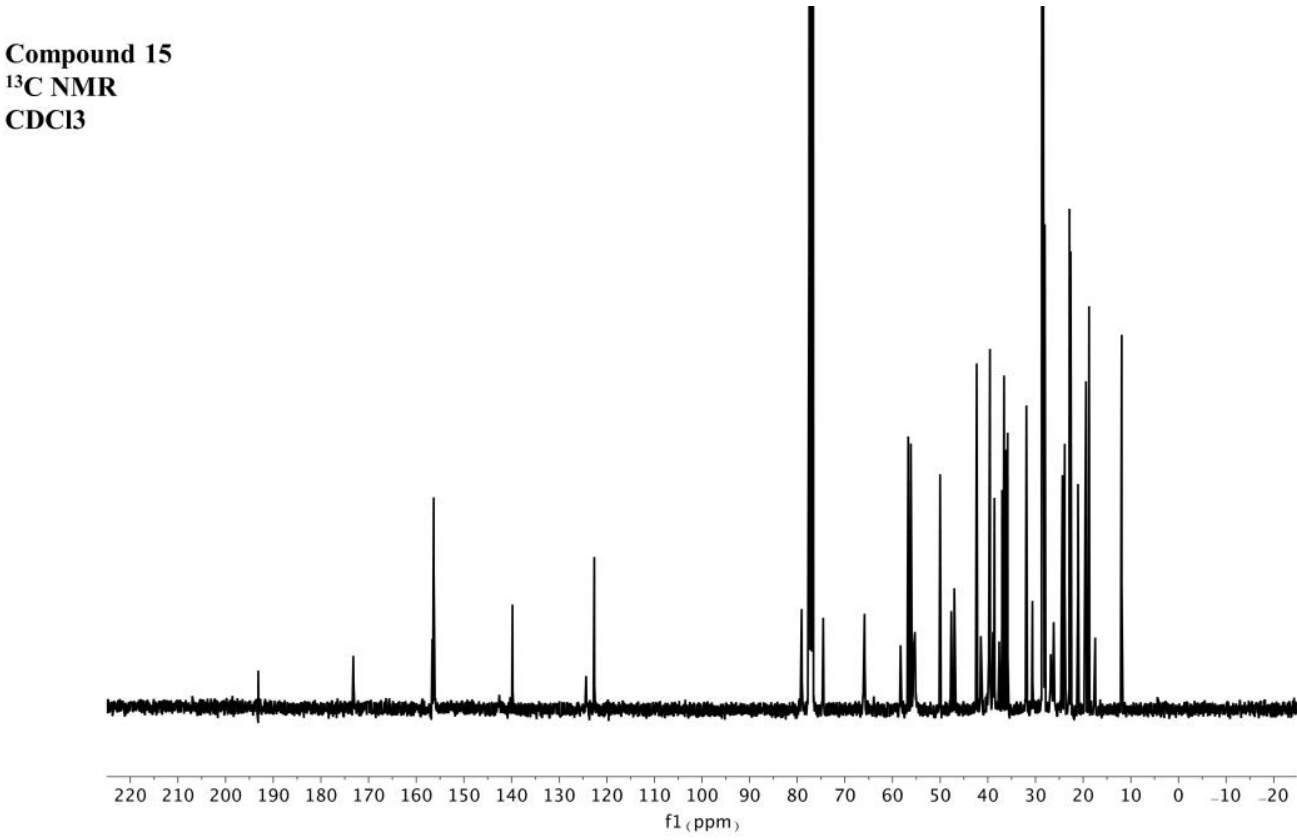

Figure S15. ${ }^{13} \mathrm{C}$ NMR spectrum of compound 15 in $\mathrm{CDCl}_{3}$. 
Compound Chol-S-G1

${ }^{1}$ H NMR

MeOD
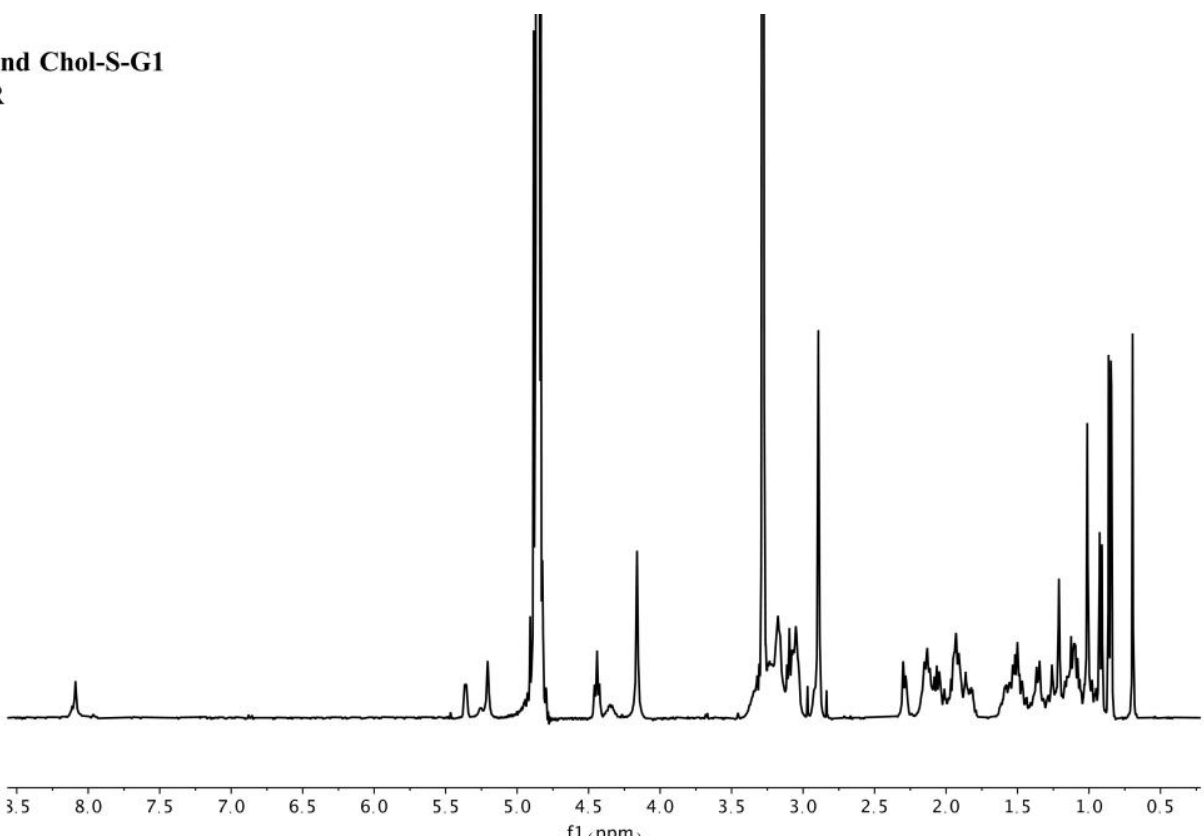

Figure S16. ${ }^{1} \mathrm{H}$ NMR spectrum of Chol-S-G1 in $\mathrm{CD}_{3} \mathrm{OD}$.

Compound Chol-S-G1

${ }^{13}$ C NMR

MeOD

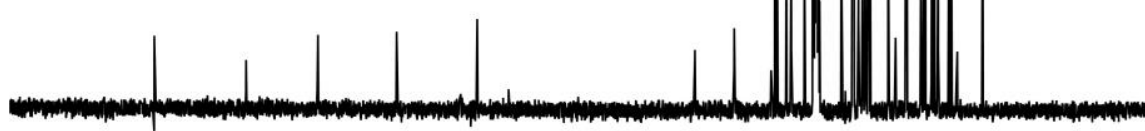

$\begin{array}{llllllllllllllllllllllllll}220 & 210 & 200 & 190 & 180 & 170 & 160 & 150 & 140 & 130 & 120 & 110 & 100 & 90 & 80 & 70 & 60 & 50 & 40 & 30 & 20 & 10 & 0 & -10 & -20\end{array}$ $\mathrm{f} 1$ ( $\mathrm{ppm}$

Figure S17. ${ }^{13} \mathrm{C}$ NMR spectrum of Chol-S-G1 in $\mathrm{CD}_{3} \mathrm{OD}$. 


\section{References}

1 E. R. Gillies and J. M. J. Fréchet, J. Am. Chem. Soc. 2002, 124, 14137-14146.

2 P. Wu, M. Malkoch, J. N. Hunt, R. Vestberg, E. Kaltgrad, M. J. Finn, V. V. Fokin, K. B. Sharpless and C. J. Hawker, Chem. Commun. 2005, 5775-5777

3 A. C. Rodrigo, A. Barnard, J. Cooper and D. K. Smith, Angew. Chem. Int. Ed., 2011, $50,4675-4679$

4 H. F. M. Nelissen and D. K. Smith, Chem. Commun. 2007, 3039-3041.

5 D. Alberti, A. Toppino, S. Geninatti Crich, C. Meraldi, C. Prandi, N. Protti, S. Bortolussi, S. Altieri, S. Aime and A. Deagostino, Org. Biomol. Chem. 2014, 12, 2457-2467.

6 D. Izhaky and L. Addadi, Chem. Eur. J. 2000, 6, 869-874.

7 A. Barnard, P. Posocco, S. Pricl, M. Calderon, R. Haag, M. E. Hwang, V. W. T. Shum, D. W. Pack and D. K. Smith, J. Am. Chem. Soc. 2011, 133, 20288-20300.

8 D. Marson, E. Laurini, P. Posocco, M. Fermeglia and S. Pricl, Nanoscale, 2015, 7, 3876-3887.

9 E. Vanquelef, S. Simon, G. Marquant, E. Garcia, G. Klimerak, J. C. Delepine, P. Cieplak and F.-Y. Dupradeau. Nucl. Acids Res. 2011, 39, 511-517.

10 J. Wang, W. Wang, P. A. Kollman and D. A. Case, Journal of Molecular Graphics and Modelling, 2006, 25, 247-260.

11 S. M. Bromfield, P. Posocco, C. W. Chan, M. Calderon, S. E. Guimond, J. E. Turnbull, S. Pricl and D. K. Smith, Chem. Sci. 2014, 5, 1484-1492.

12 A. Barnard, P. Posocco, M. Fermeglia, A. Tschiche, M. Calderon, S. Pricl and D. K. Smith, Org. Biomol. Chem. 2014, 12, 446-455.

13 M. W. Mahoney and W. L. Jorgensen. J. Chem. Phys., 2000, 112, 8910-8922.

14 H. J. C. Berendsen, J. P. M. Postma, W. F. van Gunsteren, A. DiNola, and J. R. Haak. J. Chem. Phys., 1984, 81, 3684-3690.

15 D. Case, D. Cerutti, T. Cheatham, III, T. Darden, R. Duke, T. Giese, H. Gohlke, A. Goetz, D. Greene, N. Homeyer, S. Izadi, A. Kovalenko, T. Lee, S. LeGrand, P. Li, C. Lin, J. Liu, T. Luchko, R. Luo, D. Mermelstein, K. Merz, G. Monard, H. Nguyen, I. Omelyan, A. Onufriev, F. Pan, R. Qi, D. Roe, A. Roitberg, C. Sagui, C. Simmerling, W. Botello-Smith, J. Swails, R. Walker, J. Wang, R. Wolf, X. Wu, L. Xiao, D. York and P. Kollman, AMBER 2018, University of California, San Francisco 2018. 